International Journal of Agriculture, Environment and Bioresearch

Vol. 4, No. 04; 2019

ISSN: $2456-8643$

\title{
EVALUATION OF NEEM (AZADIRACHTAINDICA) EXTRACT CONCENTRATION ON POST-HARVEST ROT OF CARICAPAPAYA
}

\author{
${ }^{*}$ Aji, P.O., ${ }^{2}$ Tunwari, B.A. and ${ }^{1}$ Japhet M.T. \\ ${ }^{1}$ Department of Biological Science, Federal University Wukari, Katsina - Ala Road, P.M.B. 1020, Wukari, Taraba \\ State, Nigeria. \\ ${ }^{2}$ Department of Crop Production and Protection, Federal University Wukari, Katsina - Ala Road, P.M.B. 1020, \\ Wukari, Taraba State, Nigeria.
}

http://doi.org/10.35410/IJAEB.2019.4421

\begin{abstract}
In this study, the antifungal effect of aqueous and ethanol extracts of Azadirachtaindicaon the growth of fungal pathogen associated with postharvest rot of pawpaw was investigated. Four different extract concentrations were used in this research $25 \%, 50 \%, 75 \%$ and $100 \%$ in a sterile distilled water and ethanol. Two fungi were isolated from rotten papaya fruits collected from three different markets in Wukari, namely; Old market, new market and yam market. The fungi isolated were identified as Aspergillusniger and Rhizopusstolonifer. Pathogenicity test revealed that Aspergillusniger, and Rhizopusstolonifer are capable of inducing rot hence caused rot in healthy pawpaw fruits after 5 days of inoculation, with Rhizopusstolonifer being the most virulent. Ethanol extract proved to be more potent. Inhibition of fungal growth increased with a corresponding increase in extract concentration. The fungitoxic potential of this plant extracts on rot inducingfungi of pawpaw recommends their use to famers as alternative to commercial / synthetic fungicides.
\end{abstract}

Keywords: Evaluation, Neem Extract Concentration, Post-harvest rot, Carica papaya

\section{INTRODUCTION}

Pawpaw (Carica papaya L.) also called Idekpe in Yoruba, Gwanda in Hausa, Okur in Igbo and Gbeika in Jukun, (the dominant language in the study area) belongs to the familyCaricaceae constituting of four genera and thirty one species. The papaya originated in Tropical South America, possibly in the area between Mexico and Central America in the $15^{\text {th }}$ century (Menzel, 1994). It is a widely grown pan tropical fruit used for local consumption and assumes some importance in trade. Historically, in the $16^{\text {th }}$ century, the seeds of papaya were transported to West Indies, Philippines, Africa and the Indo-Pak subcontinent in the $17^{\text {th }}$ century (Reid, 1990).

It is one of the leading fruits in respect of acreage and per hectare production. Recently, 1.25 metric tons of papaya were produced from an area of about 1.24 thousand hectares of land with an average yield of 7 ton/ha (BBS, 2011). In some countries like Nigeria, yield of papaya, in fact, is far below compared to other countries of the world (Chowdhury, 2008). Several species of Caricaceae have been used as remedy against a variety of diseases (Alabiet al., 2012). Carica papaya is a neutraceuticalplant having a wide range of 
pharmacological activities. The whole plant has its own medicinal value. Papaya is a powerhouse of nutrients and is available throughout the year. It is a rich source of three powerful antioxidant ( vitamin $\mathrm{C}$, vitamin $\mathrm{A}$ and vitamin $\mathrm{E}$ ), the minerals(magnesium and potassium), the $\mathrm{B}$ vitamin (pantothenic acid and folate) and fiber (Aravindet al., 2013). The black seeds of papaya are edible and have a sharp, spicy taste. They are sometimes ground and used as a substitute for black pepper. Dried papaya seeds actually look quite similar to peppercorns and can be used in just the same way. Grinding a couple over a meal, especially protein rich meals, is a simple way to add extra enzymes to your diet and improve your digestive health. The papaya seeds are very pungent and peppery, making them almost unpalatable. However the seeds seem to have more potent medicinal valuesthan the flesh. Papaya seeds have antibacterial properties and are effective against E. coli, Salmonella and Staphylococcus infections. Papaya seeds may protect the kidneys from toxin induced kidney failure. Papaya can eliminate intestinal parasites, cure for piles and typhoid and has anti-helminthic and antiamoebic properties (Aravindet al., 2013). The seeds of papaya have antimicrobial activity effective against Trichomonasvaginalisstrophozoites. It could also be used in urinogenitaldisorder like trichomoniasis with care to avoid toxicity. The seeds, irrespective of its fruit maturity stages have bacteriostatic activity on gram positive and negative organisms which could be useful in treating chronic skin ulcer. However, little information exists on the antimicrobial property of C. papaya dried and fresh leaves (Alabiet al., 2012). Recently, antifertility (Lohiaet al., 1999) anthelminthic,(Satrijaet al., 1995) and anti-inflammatory activity (Oladunmoye, and Osho, 2007) have been reported. C. papaya seeds possess moisture, proteins, fatty acids, and phospholipids, such as phosphotidylcholine and cardiolipin. Other compounds present in seeds are carpaine, benzyl isothiocynate, benzyl glucosinolate, etasitosterol,caricin, enzyme myrosin. The well-studied proteinases from papaya are papain, chymopapain, caricain, and glycylendopeptidase. Papain occurs in all parts of the tree except the root (Anonymous, 1992). Fruit and seed extracts have antibacterial activity against Staphylococcus aureus, Bacillus cereus, Escherischia coli, and Pseudomonas aeuroginosa(Emeruwa, 1982). The juice is used for curing warts, cancer, and tumors. Leaves have been poultice into nervous pains, elephantoid growths (Asolkaret al., 1992). The antihyperglycemic effect of unripe mature fruits and seeds of Caricapapaya have also been reported (Olagunja, et al. 1995; Adeneye and Olagunja, 2009). Papaya leaves are made into tea as a treatment for malaria. Antimalarial and antiplasmodial activity has been noted in some preparations of the plant, the leaves of the papaya plants contain chemical compounds of karpain, substance which kills microorganisms that often interfere with the digestive function (Udohet al., 2005).

Despite the nutritional and health importance attached to pawpaw, the availability of the fruit is reduced due to high level of postharvest loss (Mondalet al., 1995). Spoilage in pawpaw can also be referred to as rot or decay. Spoilt pawpaw fruits is characterized by excess softening, mycelia growth, loss of moisture, unpleasant odour, shrinkage and total drying up of water in the fruits (Franzier and Westhoff, 1999). The spoilage may be caused by microorganisms, insects and rodents attack, physical injury such as bruising and freezing as well as chemical breakdown of the fruit may also lead to deterioration in quality of the fruit. The occurrence of spoilage in fruits by microorganisms depends on the types of organisms present and whether the fruit under its existing condition of storage can support the growth of any or all of them. Only certain species 
out of many of the organisms present in a fruit will be able to thrive well and spoil it. Spoilage by microorganisms may be influenced by some qualities such as water content, $\mathrm{pH}$ value, temperature, texture and nutrient composition of the fruit (Lloyd, 1993). Charley (1999) observed that fresh fruits carry out the physiological function of respiration, thereby absorbing and releasing gases and other materials from and to the environment. This condition makes them susceptible to microbial infection under condition of high ambient temperature and relative humidity which lead to their deterioration during post-harvestperiod. Physiological stability of fruit varies, thus the main damage to the quality of the fruit does not occur generally until the microorganisms have gained access to the living tissues through the skin. Fruits come in contact with the disease causing organisms through different sources such as field infections or during harvesting if it comes in contact with the soil which is an important factor that aids spoilage of stored fruits.Air is another factor responsible for spoilage of fruits during their post-harvest period. Fungal spores are always in the air, these spores and other particulate ones constitute the air spora (Holtmeyer and Wallin, 1981). Also, transporting equipment after harvesting such as sacks, basins, baskets e.t.c. can serve as major sources of transmission of the pathogens. Water used in washing the fruits may be contaminated with large numbers of microbes and as such transfer them directly to the fruit and due to the high nutritional constituents of the fruits; they serve as a fertile ground for microbes especially fungi (Salunkhe, 1974). One of the major reasons of postharvest losses of papaya production is fungal diseases.Ripe Caricapapaya fruits suffer from various postharvest diseases all over the world. In some countries, there is little information available on the postharvest fungal diseases of ripe papaya which may occur during the growing season, at harvesting, handling, transport and postharvest storage and also during marketing, or after purchasing by the consumer. The causal pathogens of the diseases invade the fruits and can cause considerable damage thus rendering it unmarketable. The postharvest fruit rots bring about a big loss in fruit business which provokes price hike (Uddin, 1995). Assessment of prevalence of the diseases and fruit losses is the key factors in determining the economics of disease management and development of safe management strategies.

\section{MATERIALS AND METHODS}

\subsection{Materials used for isolation of pathogens}

Potato dextrose agar, Distilled water, Mercury chloride, Vaseline, Cotton wool, Aluminium foil paper, Ethanol, Streptomycin, sterile spatula, Whatman Filter Paper, Cheesecloth, Conical flask, Petri dish, Cork borer, inoculating needle, rotted pawpaw fruit.

\subsection{Collection of pawpaw}

A total of nine (9) infected pawpaw fruits were collected from six (6) different traders in three different markets (new market, old market and Yam market) in Wukari town (three fruits from each market). The fruits were collected into a sterile polythene bag and brought to the laboratory for the research.

\subsection{Collection of Plant materials, preparation and determination of the plant extract concentration}

Fresh, young leaves (Plate I) of Azadiratchaindica(Neem) were collected from the Staff quarters, Federal University Wukari.The leaves werethoroughly washed with distil waterand were air- dried until were completely dried to the point that permitted milling. The dried sampleafter milling was sieved to obtain powdered processed sample used for theextraction. 
Usingcold solvent extraction method (Harbone,1973; Junaidet al., 2006; Doughariet al., 2007) $25 \mathrm{~g}, 50 \mathrm{~g}, 75 \mathrm{~g}$ and $100 \mathrm{~g}$ portion of the processed sample was mixed with $100 \mathrm{ml}$ of eachsolvent (Aqueous and ethanol) separately in a bottle to produce 25\%,50\%, 75\% and $100 \%$ extract concentrations respectively. The extracts were sieved through sterile filter paper and stored in sterile conical flask which was later usedfor growth inhibition.

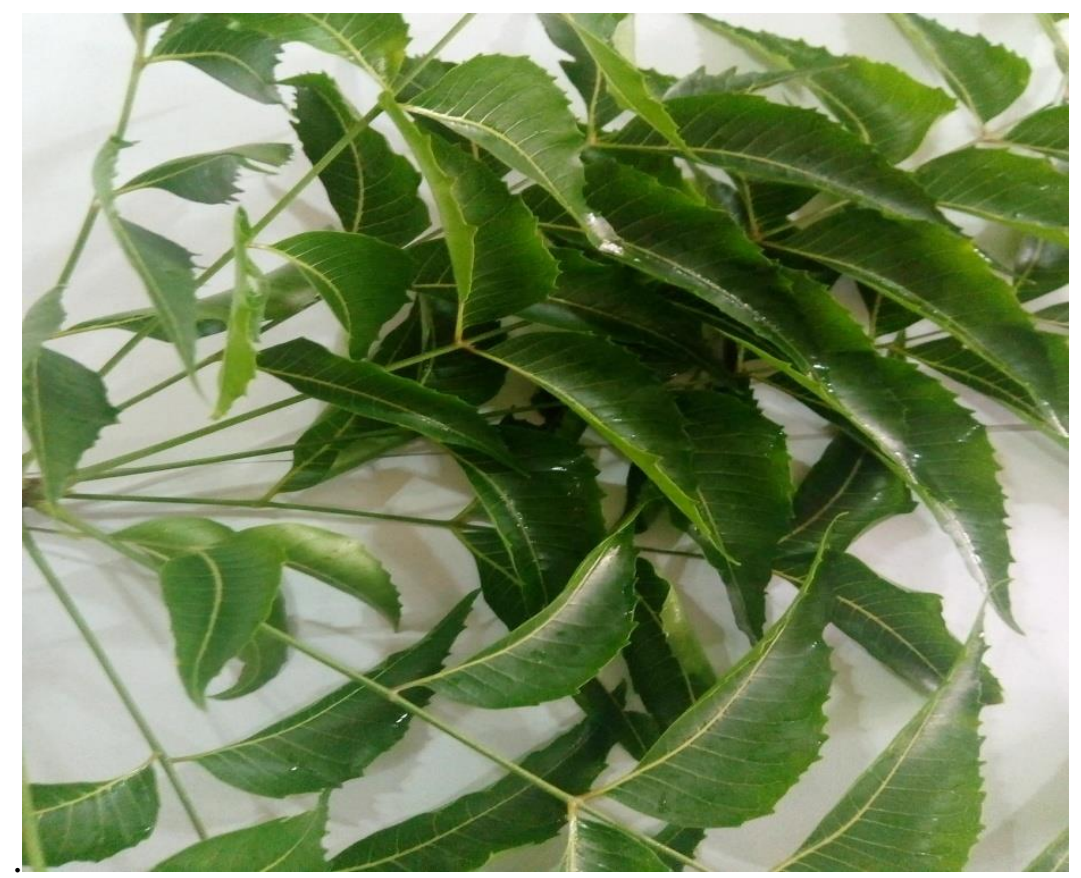

PlateI. Neem leaves used for the extraction

\subsection{Experimental Design}

The completely randomized design was used for the experiment. The research was aimed at the study of post-harvest spoilage of Carica papaya fruit. It involved isolating a particular fungal pathogen associated with postharvest rot of pawpaw and using 25\%, 50\%, $75 \%$ and $100 \%$ concentrations of leaf extract of Azadiratchaindica(Neem) on the isolated fungi, while distil water without leaf extract as a control treatment.

\subsection{Statistical Analysis}

The data collected were subjected to analysis of variance (ANOVA) according to Gomez and Gomez (1984) and means were separated using least significant difference (LSD) at 0.05 probability level according to Scheffer (1953).

\subsection{Results and Discussions}

Ethanol neem extract (Table 1) and aqueous neem extract (Table 2) shows the efficacy of the extract on mycelia growth of Aspergillusniger and Rhizopusstolonifer at different times ranging from $24 \mathrm{hrs}$ to $120 \mathrm{hrs}$ and with varying extract concentrations ranging from 25\%,50\%, 
$75 \%$ and $100 \%$. This result showed an increased in the mycelia growth inhibition with a corresponding increase in extract concentration. The result shows a significant difference within the medium of extraction, with $100 \%$ concentration being more effective. This agrees with the findings of Suleiman (2010) who reported a significant difference between mycelia growth recorded on various plant extract concentrations. This suggests that there is difference in the solvent soluble antifungal element in the leaf extract as reported by Iwu (1993) and Sofowora (1997). There was significant difference between the medium of extraction. Ethanol extract proved to be more potent. This agrees with the reports of Ekwenye and Elegalam, (2005) on garlic who attributed this to the fact that ethanol is an organic solvent and will dissolve organic compounds better, hence liberate the active compounds (phytochemical) required for antifungal activity. This also is in line with the results obtained by Sangoyomi, (2004) on yam rot and that of Suleiman (2010) on post-harvest rot of yam, who reported a highly effective inhibition with extract from Azadirachtaindica. The difference in the fungitoxic within the extraction medium can also be as a result of the different susceptibility of each of the test isolates to different concentrations of the extract, which agrees with the findings of Amadioha, (2000) who reported effect of some leaf extract against Rhizopusoryzae at varying degrees.

Table 1: Effect of ethanol neem extract on mycelia growth $(\mathrm{mm})$ of Rhizopusstolonifer in Wuklari Taraba State

\begin{tabular}{|c|c|c|c|c|c|c|}
\hline Concentration $(\%)$ & & $75 \mathrm{hrs}$ & & $96 \mathrm{hrs}$ & & $120 \mathrm{hrs}$ \\
\hline 25 & 2.27 & 3.17 & & 4.50 & & \\
\hline 50 & 2.13 & 2.77 & 3.40 & & & \\
\hline 75 & 2.07 & 2.77 & 3.20 & & & \\
\hline 100 & 1.93 & 2.07 & & 2.80 & & \\
\hline Control & 5.00 & & 7.00 & & 8.10 & \\
\hline Mean & 2.68 & 3.55 & & 4.40 & & \\
\hline LSD & & 0.39 & 1.12 & & 0.40 & \\
\hline
\end{tabular}

Table 2 Effect of aqueous neem extract on mycelia growth (mm) of Aspergillusniger in wukari

\begin{tabular}{lllcc}
\hline Concentration (\% ) 24hrs 48hrs & $72 \mathrm{hrs}$ & $96 \mathrm{hrs}$ & $120 \mathrm{hrs}$ \\
\hline & & & & \\
25 & 1.50 & 3.50 & 5.83 & 7.77 \\
8.00 & & & & \\
50 & 0.933 .33 & 5.10 & 7.73 & 7.90 \\
75 & 0.673 .17 & 4.67 & 6.93 & 7.87 \\
100 & 0.63 & 2.73 & 4.40 & 6.93 \\
7.83 & & & & \\
$\quad$ Control & 1.50 & 4.00 & 4.50 & 6.80 \\
8.00 & & & &
\end{tabular}


Vol. 4, No. 04; 2019

ISSN: $2456-8643$

\begin{tabular}{lcccc}
\hline Mean & 1.053 .35 & 4.90 & 7.23 & 7.92 \\
LSD & 0.741 .18 & 1.080 .45 & 0.40 & \\
\hline
\end{tabular}

The fungi isolated during the study were identified as Aspergillusnigerand Rhizopusstolonifer. These were frequently isolated from rotten fruits. These organisms have been reported to cause extensive rot of fruits. (Ezeand maduewesi 1990). This result is in agreement with the reports of Ugwuanyi and Obeta, (1996) on post-harvest rot of cocoyam. The isolation of more than one pathogenic organism from a particular fruit confirms the possibility of multiple infections whose combined effect may cause rapid rottening of fruit. This agrees with the reports of Sangayomi, (2004) which also reported that in most cases, fungi gain entrance into fruits through natural openings and wounds created during harvesting, transportation, handling and marketing. However, Okigbo and Nmeka (2005) noted that roots, tubers and fruits at time of harvest may already be infected by pathogens derived from diseased foliage or roots of the mother plant. (Suleiman, 2010) reported the influence of climatic conditions on the occurrence of fungal pathogen, their ecological requirements and the competitiveness of the species. This was also reported by Dodd et al., (1997). Similar report was obtained by Johnson, (1994) and Estrada, (1994) in their work on post-harvest rot of mango which suggested that Anthracnose becomes more than stem root rot fungi under humid conditions.

\section{REFERENCES}

Adeneye, A. A. and Olagunja, J. A., (2009). Preliminary hypoglycemic andhypolipidemic activities of aqueous seed extract of Caricapapaya.Linn in Wistar rats. Biol Med.; 1:1-10.

Alabi, O.A, Haruna, M.T, Anokwuru, C.P, Jegede, T., Abia, H., Okegbe, V. and Esan, E. (2012).Comparative

studies on antimicrobial properties of extracts of fresh and dried leaves of Carica papaya (L) on clinical bacterial and fungal isolates. Pelagia Research Library. 3 (5):3107-3114.

Anonymous (1992).The Wealth of India.Raw materials.Ca-Ci, Publication and Information Directorate, CSIR,

New Delhi, India.1992. p. 287-93.

Aravind. G, Debjit B, Duraivel. S, Harish. G. (20130.Traditional and Medicinal Uses of Carica papaya. Journal of

Medicinal Plants $\quad$ Studies. 1(1): 7-15.

Asolkar L.V., Kakkar K.K., Chakre O.J. Glossary of Indian Medicinal Plants with active principles. Part 1 (A-

K).Publications by Information Directorate, CSIR New Delhi. 1992. p. 171-3.

BBS.(2011). Year Book of Agricultural Statistics of Bangladesh.Bangladesh Bureau of Statistics.Statistics BBS. 2011. Year Book of Agricultural Statistics of Bangladesh. Bangladesh Bureau of Statistics. 
Chowdhury, M.G.F., Islam, M.N., Islam M.S., Islam, A.F.M.T. and Hossain, $\quad$ M.S. (2008). Study on preparation and shelf-life of mixed juice based on wood apple and papaya. Journal of soil and nature, 2 (3):50-60.

Dodd J.C,PrushyD,Jefferies P,(1997). Fruits diseases. In: Mango: Botany, production and uses. R.E. litz (ed.) CAB international,Oxon,UK.57-280.

Doughari J.H, Elmahmood A.M, Manzara S, (2007). Studies on the antibacterial activity of root extracts of Carica

papaya.L. Afri. J.Microbiol. Res. 1:37-41.

Ekwenye U.N, Elegalam N.N, (2005). Antibacterial activity of Ginger (Zingiberofficinale Rosecoe) and garlic

(Allium sativum.L.) extracts on Escherichia coli and Salmonella typhi. J. Molecular Med. and Adv.Sci. 1(14): 411- 416.

Emeruwa A.C. (1982). Antibacterial substance from Carica papaya fruit extract. J Nat Prod.1982; 45:123-7.

Estrada A.B,(1994). Epidemiology and control of MangoAnthracnose.Canterbury, Kent,UK University of Kent,PhD thesis.

Eze C.C, Maduewesi J.N.C, (1990). Relation of traditional Methods to the magnitudof storage losses of cocoyam

(Colocasiaesculenta (L) schott).Nig. J. Plant Protection 13:26 34.

FranzierW.C,Westhoff D.C, (1991). Food Microbiology (3rd ed.) Tata McGrawHill publishing Company Ltd. New

Delhi pp 17-21.

Harbone JB (1973). Phytochemical methods. A guid to Modern technique of plant analysis. Chapman and Hall, New

York.

Gomez, K. A and Gomez A.A. (1984). Statistical procedure for Agricultural research ( $2^{\text {nd }}$ edition). John wily and

sons. Pp.680.

Johson G.I, (1994). Stem end rot.In: compendium of tropical fruits diseases. R.C ploetz,G.AZevtmyer,W.T

Nishijima, K.G Rohrbach and H.D Ohr (eds),St. PaulN.M. 38-41.

Juanid S.A, Olabode A.O, Owuliri F.C, Okworiu A.E.J, Agina S.E (2006). The antimicrobial properties of Occimum

gratissimum. The antimicrobial properties of Occimumgratissimum (Poir) rot disease. Nig. J. Mycol. 2(1): $166-167$

Harbone,T.B.(1993).Phytochemical method. $2^{\text {nd }}$ editionchapman and Hall publication,London,New York,Pp288.

Holtmeyer M.G, Wallin J.R (1981). Incidence and Distribution of airbornespores of Aspergillusflavus, In: Plant 
Disease 6: 54-60.

Iwu, M.W. Duncan, A.R. Okunji, C.O (1999).New antimicrobials of plantorigin.(Janick,J. (ed.), Perspectives on New Crops and New uses). ASHS Press, Alexandria

Lloyd B.B (1993). Fungi in food. An Overview In: Encyclopeadia of Food Science, Food Technology and Nutrition.

Academic press Lmtd London pp. 4327-4337.

Lohiya NK, Mishra PK, Pathak N, Munivannan B, Jain SC. Reversible azospermia by oral administration of the

benzene chromatographic fraction of the chloroform extracts of the seeds of Carica papaya inrabbits. AdvContracept 1999; 15:141-148

Mondal, M.F., Rahman, M.A. and Pramanik , M.A.J.( 1995). Effects of different post-harvest treatments on physio-

chemical changes and shelf life of mango. Bangladesh horticulture,.23(1\&2):1-5.

Menzel C. (1994). Tropical and subtropical Fruits. Encyclopedia of Agricultural Science 4: 375378. Robert A.S,

Ellen S.N (1998).

Oladunmoye M.K, Osho I.B. Anti-inflammatory activity of ethanolic leaf extract from Carica papaya in rats, orogastrically dosed with Salmonella typhiand Staphylococcus aureus.

Olagunja J.A, Ogunlana C.O, Gbile Z, (1995). Preliminary studieson the hypoglycemic activity of ethanolic extract

of unripemature fruits of Carica papaya. Nig. J Biochem., Mol. Biol. 1995; 10:21-3.

Okigbo R.N, Nmeka I.A (2005). Control of yam tuber rot with leaf extracts of Xylopiaaethiopia and Zingiber

officinale. Afri. J. Biotechnol. 4(8): 804-807.

Reid,R.L,(1990).Fruit crops in the manual of Australian Agriculture. Reid R.L(edition).Butterworth, Sydney. pp 200-201.

Salunkhe D.K, (1974). Development in Technology of storage and handling of fresh fruits and vegetables. Critical

Review of Food Technology 3: 15-54

Sangoyomi T.E, (2004). Post-harvest fungal deterioration of yam (DioscorearotundataPoir) and its control. $\mathrm{PhD}$

Thesis IITA, Ibadan Nigeria. I79pp.

Satrija F, Nansen P, Murtini S, He S. (1995).Anthelmintic activityof papaya latex against patent Heligmosomoides

polygyrusinfections in mice. J.Ethnopharm 1995; 3:161-4.

Scheffer, H. (1953). A method of judging all contract of analysis of variance. Biometric 40: 104107

Singfield P.(1998). Report No- papaya and Belise, Belise development trust. 
Sofowora A., (1997). Medicinal plants used in traditiponal medicine in Africa. First edition, John wiley and sons, Chichester,New York. Pp128-129.

Uddin M. (1995). Market diseases of papaya and their control. MS thesis.Department of Plant Pathology.

Bangladesh Agricultural Univetrsity.Mymensingh.

Udoh P, Essien I, Udoh F. (2005). Effect of Carica papaya (paw paw) seeds extract on the morphology of pituitary-

gonadal axis of male Wistarrats. Phytother Res.19:1065-8.

Ugwuanyi J.O, Obeta J.A. (1996). Fungi associated with storage rots of cocoyam.(Colocasiaspp) in Nsukka, Nig. Mycopathol.134(1): 21-25. 